\title{
Analysis of the Effect of Asset Growth, Profitability, and Company Size on Capital Structure (Empirical Study in Mining Sector Companies in Indonesia Stock Exchange)
}

\author{
Alpon Satrianto ${ }^{1}$, Candrianto Candrianto ${ }^{2}$, Mia Ayu Gusti ${ }^{3}$, Egy Juniardi ${ }^{4}$, Mutiara Novenica ${ }^{5}$ \\ ${ }^{1}$ Universitas Negeri Padang, Padang, Indonesia, $\triangle$ alpon.unp@gmail.com \\ ${ }^{2}$ Politeknik Negeri ATI Padang, Padang, Indonesia, $\square$ candriantokemenperin@gmail.com \\ ${ }^{3}$ Universitas Negeri Padang, Padang, Indonesia, $\square$ ayugustimia@gmail.com \\ ${ }^{4}$ Universitas Negeri Padang, Padang, Indonesia, $\square$ gyejuniard@gmail.com \\ ${ }^{5}$ Universitas Putra Indonesia, Padang, Indonesia, $\square$ mutiaranovenica@gmail.com
}

\begin{abstract}
The purpose of this research is to determine 1) the effect of asset growth rate to capital structure of mining companies listed in Indonesia Stock Exchange 2) the effect of profitability to capital structure of mining companies listed in Indonesia Stock Exchange 3) the effect of firm size to capital structure of mining companies listed in Indonesia Stock Exchange. The research sample are 76 mining companies listed in Indonesia Stock Exchange around 2011-2014. This research used purposive sampling method. The statistical methods used in this research are multiple regressions. The results of this research indicate that: (1) asset growth rate have negative and no significant effect to capital structure of mining companies listed in Indonesia Stock Exchange (2) profitability have negative and significant effect to capital structure of mining companies listed in Indonesia Stock Exchange and (3) firm size have positive and significant effect to capital structure of mining companies listed in Indonesia Stock Exchange.
\end{abstract}

Keywords: asset growth rate, profitability, firm size, and capital structure

\section{Introduction}

The increase in fuel prices at the end of May 2008 quickly increased the annual inflation rate (year on year), which amounted to $11.03 \%$. The high level of commodity prices due to the increase in fuel prices plus the threat of the global food crisis caused a high rate of inflation in Indonesia. High inflation can cause a decline in people's purchasing power. The increase in the inflation rate has also triggered Bank Indonesia to raise its benchmark interest rate, the August 2008 BI rate of $9.5 \%$ to reduce the increasingly high inflation rate. The increase in the BI rate also led to an increase in loan lending rates, which in turn would cause the mining sector to be affected, namely the mining sector experienced a slowdown in growth in assets and sales in 2008, amounting to $22.9 \%$. Rising interest costs and weakening purchasing power will increase the risk of bankruptcy. Therefore, companies in the current situation must be more wise in determining funding decisions that will be made especially in the use of debt. (Ibnu purna, Hamidi and Prima, 2009).

A good funding decision is seen from the capital structure. Good capital structure is an optimal capital structure that is a condition where a company can use a combination of debt and equity ideally, which can balance the value of the company and the cost of its capital structure. Riyanto (2001: 209) states that companies prefer internal funds rather than external funds. If internal funds are insufficient then use external funds. In the perspective of Pecking Order Theory, according to Myers in Husnan 2000: 26) states that companies are more likely to choose funding that comes from internal rather than external companies. The use of internal funds takes precedence over the use of external sources of funds. The order put forward by this theory in terms of funding is the first retained earnings followed by the use of debt and the last is the issuance of new equity. The selection of the sequence of funding shows that this funding is based on the level of cost of funds from these sources which also relates to the level of risk of an investment.

Capital structure is the proportion in determining the fulfillment of corporate spending needs with long-term funding sources that come from internal funds and external funds. Capital structure can be 
seen in the proportion of long-term debt owned by companies that can be measured using LTDER (Long Term Debt to Equity Ratio) according to Weston (1996), this ratio shows the comparison between the amount of long-term debt given by creditors (originating from outside company) with the amount of own capital provided by the owner of the company (from within the company) to finance the company's operations.

According to Brigham and Houston (2001), the size of the capital structure used by companies, is influenced by many factors including, the level of growth (assets), sales stability, asset structure, liquidity, profitability, tax, and management attitudes. Whereas according to Riyanto (2001), the capital structure of a company is influenced by many factors, where the main factors are: interest rates, earnings stability, composition of assets, and company size. Due to the many factors that influence the company's capital structure, making researchers focus their research on the level of asset growth, profitability, and company size because there are inconsistencies from the results of previous studies. Where there are factors that prove influential in a study, but not necessarily influence on other studies. This can occur because of differences in sample, time of study, and population studied. Based on the theories of capital structure and various studies that have been conducted, this study uses the basis of the Pecking Order theory as the main basis of research. This study aims to examine and analyze the level of growth of assets, profitability and size of the company towards the capital structure of mining sector companies in the Indonesia Stock Exchange for the period 2011-2014.

\section{Methods}

\section{Population and Sample}

The population used in this study consisted of all mining sector companies listed on the IDX, with observations from 2011 to 2014. In this study the sample selection method used a purposive sampling method. The criteria in this study are mining sector companies that are listed on the IDX, publish periodic financial statements during the observation period, publish financial statements in rupiah and the company always generates profits or in other words does not get negative profits during the observation period. Based on these criteria, there are 76 companies included in the study sample. Data from this study comes from data published by the IDX.

\section{Operational Definition and Variable Measurement Capital Structure}

Mardiyanto (2009) states that capital structure is defined as the composition and proportion of long-term debt and equity set by the company. This variable is measured using the LTDER ratio. According to Mardiyanto (2009) LTDER is calculated with the following formulations:

$$
\text { LTDER }=\frac{\text { LongtermDebt }}{\text { OwnerEquity }}
$$

\section{Asset Growth Rate}

Asset growth is a change (increase or decrease) in total assets owned by the company. Determination of proxy to calculate asset growth in this study refers to Rafiq (2008), which is calculated as the percentage change in assets in a given year against the previous year.

$$
\text { Growth }=\frac{\text { Totalassett }- \text { Totalasset }(t-1)}{\text { Totalasset }(t-1)}
$$

\section{Profitability}

Company profitability is calculated to determine the extent of the ability of total assets (investment decisions) in generating net income from the company's operations. Profitability is measured using the ROA ratio. The measure of profitability in this study refers to Mardiyanto (2009). The ROA ratio can be formulated as follows:

$$
\mathrm{ROA}=\frac{\text { Net Profit }}{\text { TotalAsset }}
$$




\section{Company Size}

Company size is a description of the company's financial capabilities in a certain period. Financial capability seen from several sides, one of which is seen from the net sales owned by the company. According to Haruman (2008) company size relates to flexibility and the ability to obtain funds and earn profits by looking at the number of sales of the company. The number of sales is used as an indicator of the size of the company because if the size of the company increases, the number of sales owned will also increase.

$$
\text { SIZE }=\text { Ln Total Sales }
$$

\section{Data analysis technique}

The data analysis method used in this study is panel data regression analysis. The analysis is used to see the effect between the level of growth of assets, profitability, and firm size on the capital structure of the mining sector companies on the IDX.

\section{Results and Discussion}

\section{Descriptive statistics}

This descriptive statistic is used to give an overview of the minimum value, maximum, average (mean), and standard deviation of each research variable, namely the growth rate of assets, profitability, company size and capital structure in mining sector companies on the IDX. Descriptive results can be seen in Table 1 below:

Table 1 Descriptive Statistics from Research Variables

\begin{tabular}{cccccc}
\hline & $\mathrm{N}$ & Min & Max & Mean & SDV \\
\hline LTDER & 76 & .0050 & 1.68 & .46 & .48 \\
\hline Growth & 76 & -.1006 & 137.24 & 3.21 & 18.59 \\
\hline ROA & 76 & .0015 & .46 & .089 & .097 \\
\hline SIZE & 76 & 6.1738 & 17.53 & 1.44 & 2.07 \\
\hline Valid N & 76 & & & & \\
(listwise) & & & & &
\end{tabular}

Source: Results of SPSS, 2019

\section{Classical Assumption Test Results Normality test}

Good data is data that has a normal distribution pattern (data is spread normally). This means that the data is centered on the average and median values. In detail the results of normality testing can be seen in Table 2 below:

Table 2 Normality Test Results

\begin{tabular}{cc}
\hline & $\begin{array}{c}\text { USTD. } \\
\text { Residual }\end{array}$ \\
\hline Asymp. Sig. (2-tailed) & .456 \\
\hline
\end{tabular}

Source: Result of SPSS, 2019

Based on Table 2, it can be seen that the sig. (2-tailed) value is $0.456>0.05$, which means that the variable data is normally distributed. So that means all data variables center on median and mean values. 


\section{Multicollinearity Test}

Multicollinearity test is done by TOL (Tolerance) and Variance Inflation Factor (VIF) testing methods. If the VIF value is greater than 10, then the variable has a multicollinearity problem with other independent variables. Vice versa, if the VIF value is not more than 10, then the variable does not have multicollinearity problems with other independent variables (Suliyanto, 2011).

Table 3 Multicollinearity Test Results

\begin{tabular}{ccc}
\hline \multirow{2}{*}{ Model } & \multicolumn{2}{c}{ Collinearity Statistics } \\
\cline { 2 - 3 } & Tolerance & VIF \\
\hline $\begin{array}{c}\text { Growt } \\
\mathrm{h}\end{array}$ & .981 & 1.019 \\
\hline ROA & .917 & 1.091 \\
\hline SIZE & .903 & 1.108 \\
\hline
\end{tabular}

Source: Resuls of SPSS, 2019

From Table 3, it can be seen that the VIF value of all independent variables is less than 10, so that it can be assumed that between independent variables there is no problem with Multicollinearity.

\section{Heterokedacity test}

The Heterokedacity test in this study was carried out using the graph analysis method. The graph analysis method is carried out by observing a scatterplot where the horizontal axis describes the Predicted Standardized value while the vertical axis describes the value of Residual Studentized. If the scatterplot spreads randomly above or below zero on the axis of the Regression Studentized Residual, it shows that there is no heterokedacity problem in the regression model formed

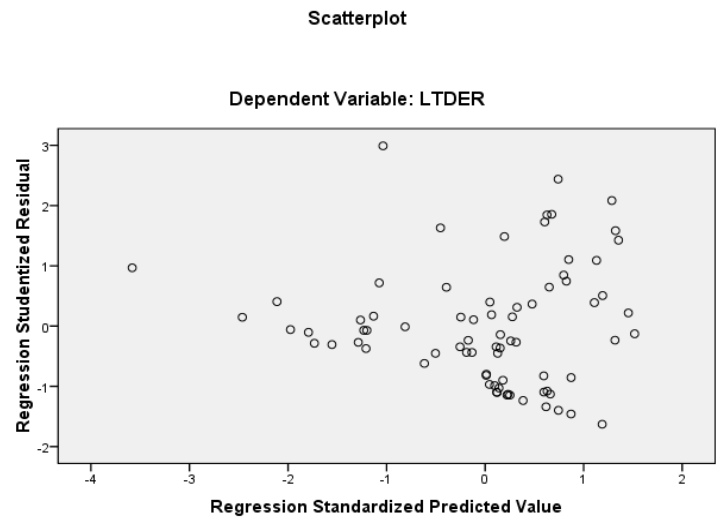

Figure 1 Heterokedacity Test

\section{Multiple Regression Analysis}

Table 4 Results of Multiple Regression

\begin{tabular}{lccc}
\hline Model & $\mathrm{B}$ & $\mathrm{t}$ & Sig. \\
\hline (Constant) & -.210 & -.572 & .569 \\
\hline Growth & -.003 & -.905 & .368 \\
\hline ROA & - & -3.808 & .000 \\
& 2.075 & & \\
\hline SIZE & .060 & 2.327 & .023 \\
\hline
\end{tabular}

Source: Resuls of SPSS, 2019 
Based on the table above the multiple regression equation in this study is as follows:

LTDER $=-0,210-0,003$ GROWTH-2,075ROA+ 0,060 SIZE

\section{F Statistics Test}

The $\mathrm{F}$ test is conducted to determine the effect of the independent variables on the dependent variable as a whole. In detail, the F test results can be seen in Table 5 below:

Table 5 F Statistic Test Results

\begin{tabular}{lcc}
\hline Model & F & Sig \\
\hline Regression & 5.744 & $.001^{\mathrm{a}}$ \\
\hline
\end{tabular}

Source: Resuls of SPSS, 2019

From table 5, it can be seen that the F test value is 5.744 with a significance level of $0.001<0.05$. So it can be concluded that the independent variables, namely the level of asset growth, profitability, and company size together have a significant effect on the dependent variable, namely the capital structure. So it can be concluded that the model is feasible to be tested.

\section{Determination Coefficient Test ( $\mathbf{R}^{2}$ Test)}

The coefficient of determination test aims to measure how far the model's ability to explain the variation of the dependent variable. In detail the R2 test results can be seen in Table 6 below:

Table $6 \mathbf{R}^{2}$ Test Results

\begin{tabular}{cc}
\hline Model & Adjusted R Square \\
\hline 1 & .159 \\
\hline
\end{tabular}

Source: Resuls of SPSS, 2019

From table 6, it can be seen that the value of Adjusted R Square obtained is 0.159. This means that the capital structure of mining sector companies listed on the Stock Exchange can be explained by the expected variable asset growth, profitability, and company size of $15.9 \%$. other variables not analyzed in this study.

\section{Hypothesis Test ( $t$ test)}

The $t$ test is carried out to know the influence of the independent variable on the dependent variable in the regression equation partially by assuming other variables are considered constant. To find out the hypothesis is accepted or rejected by comparing the value of $t$ count with $t$ table and the significance value $<0.05$. The hypothesis is accepted if the table to $\geq t$ value or - to $<-t$ table and hypothesis are rejected if the value is to $\geq t$ table or - to $\geq-t$ table.

The first hypothesis in this study states that the level of asset growth has a positive effect on the capital structure of mining companies on the IDX. From Table 5, it is known that the $-\mathrm{t}$ count $\geq-\mathrm{t}$ table $(-0.905 \geq-1.994)$ or $\operatorname{sig}>0.05(0.368>0.05)$. So that the hypothesis is rejected, meaning that the level of asset growth has no significant negative effect on the capital structure of mining companies on the IDX.

The second hypothesis in this study states that profitability has a significant negative effect on the capital structure of mining companies listed on the IDX. From Table 5 it is known that $-\mathrm{t}$ count $<-\mathrm{t}$ table $(-3.808<-1.994)$ or sig $<0.05(0,000<0.05)$. So that the hypothesis is accepted, meaning that profitability has a significant negative effect on the capital structure of mining companies on the IDX.

The third hypothesis in this study states that the size of the company has a significant positive effect on the capital structure of mining companies listed on the IDX. From Table 5 it can be seen that $\mathrm{t}$ count $\geq \mathrm{t}$ table $(2.327>1.994)$ or sig $<0.05(0.023<0.05)$. So that the hypothesis is accepted, meaning 
that the size of the company has a significant positive effect on the capital structure of the mining company on the IDX.

\section{Effect of Asset Growth Rate on Capital Structure in Mining Companies on the IDX.}

Based on the results of data processing that has been carried out, it shows that the level of asset growth has no significant negative effect on the capital structure of mining companies on the IDX. This shows that the high and low level of asset growth does not affect debt because companies that have higher total assets have sufficient funds, so they do not need debt (external) but from internal sources, namely the source of funds formed or generated by themselves within companies, for example, funds originating from non-shared profits or profits held in the company, so that it can be said that the company is spending on internal funding. This research is in line with the research conducted by Goey and Mariana (2014), Seftianne (2011), and Dilek (2009) who found that asset growth rates did not affect the capital structure.

This research is not in accordance with the theory of pecking order and research conducted by Joni and Lina (2010), Friska (2011) Ratri and Darsono (2012), namely the increase in assets followed by an increase in operating results will further increase the confidence of outsiders in the company. With the increasing trust of external parties (creditors) towards the company, the proportion of debt is greater than the equity itself. This is based on the creditor's confidence in the funds invested in the company guaranteed by the amount of assets owned by the company. Thus asset growth has a positive effect on capital structure, which means that the greater the level of growth of company assets, the greater the level of debt per asset value.

\section{Effect of Profitability on Capital Structure in Mining Companies on the IDX.}

Based on the results of data processing that has been done, it shows that profitability has a significant negative effect on the capital structure of mining companies on the IDX. With the existence of a negative relationship between profitability and capital structure shows that the greater the level of profitability obtained by the company, the company's capital structure derived from debt will decrease. Companies that have a large level of profit will also have a larger internal funding source so that this will affect the decision of capital structure or funding of a company which is in financing its business activities, such as developing a product or the need to finance investment, enabling companies to tend to use capital itself, namely internal funds first, such as in the form of retained earnings as from profits generated by the company rather than using external funds or funds originating from outside parties, namely debt so the level of debt used by the company is relatively low and will minimize the risk of bankruptcy and costs capital or high debt.

The results of this study are consistent with research conducted by Joni and Lina (2010), Seftianne (2011), Friska (2011), Ratri and Darsono (2012), Muhammad and Isnurhadi (2013), Goey and Mariana (2014) which state that profitability has a negative relationship with the capital structure. This opinion has been supported and in accordance with one of the capital structure theories, namely pecking order theory. In pecking order theory proposed by Myers and Maljuf (1984) states that companies are more likely to prioritize their own capital as a source of internal funding (internal financing) in financing or funding the company's operations and investments and this theory encourages companies that have large profits to use internal funds first in funding company activities. However, the results of this study do not support previous research conducted by Dilek (2009) which states the level of profitability influences the capital structure

\section{Effect of Company Size on Capital Structure in Mining Companies on the IDX.}

Based on the results of processed data, it can be concluded that the size of the company has a significant positive effect on the capital structure of mining companies on the IDX. Large companies tend to have large debts. This indicates a large company where the company's shares are very wide spread. Each expansion of stock capital will only have a small effect on the possibility of the loss or shift of dominant control of the company to the company concerned. Conversely, a small company 
where the shares are only spread in a small environment, the addition of the number of shares will have a large influence on the possibility of loss of dominant party control over the company concerned, thus larger companies dare to issue new shares to meet the need to finance sales growth compared with a small company.

Larger companies have access to sources of funding from various sources, so getting loans from creditors will be easier because large-sized companies have a greater probability of winning competition in the industry, whereas small-scale companies will face uncertainty, because small companies react faster to sudden changes. Therefore, it is possible for large companies to leverage more than small companies. The results of this study are consistent with the research conducted by Seftianne (2011), Ratri and Darsono (2012), Goey and Mariana (2014) which prove that firm size has a positive effect on capital structure and this is in accordance with the pecking order theory which states that, if internal funds are insufficient, the second alternative is used to use debt. When the size of the company owned is greater, the company can easily get a loan, assuming the lender believes that the company has sufficient liquidity.

But the results of this study do not support previous research conducted by Dilek (2009), Joni and Lina (2010), and Friska (2011), which states that firm size does not affect the capital structure. This shows that the company has adequate sales that are used for corporate funding and no longer need debt.

\section{Conclusions}

Based on the introduction, the study of theory and data processing as well as the discussions that have been carried out in the previous chapter, it can be concluded that 1) The level of asset growth has no significant negative effect on the capital structure of mining sector companies listed on the Stock Exchange, 2) Profitability has a significant negative effect on capital in mining sector companies listed on the IDX, 3) Company size has a significant positive effect on the capital structure of mining sector companies listed on the IDX.

Based on the results of the research that has been put forward, it can be suggested as follows: 1) Being a consideration for managerial parties in making a decision to use long-term debt. The consideration that managers can use is that companies should use the maximum amount of internal resources they have to maximize their efforts before using external resources, 2) For further researchers, with this research, researchers are expected to conduct further research related to the fundamental factors affect the capital structure so that the value of the coefficient of determination can be increased, finally modeling becomes better. And it can also replace the research object, which may be sectoral or other and increase the observation period, and it would be better to use different data processing methods to produce more accurate data processing.

\section{References}

Abor J, Biekpe N. (2009). How do we Explain the Capital Structure of SMEs in Sub Saharan Africa: Evidence from Ghana. Journal of Economic Studies. 36(1):83-97.

Brigham, E. F., \& Houston, J. F. (2001). Financial Management.Jakarta: Four Salemba.

Brigham, E. F., \& Houston. (2006). Fundamentals of Financial Management.Interpreting Ali Akbar Yulianto. Jakarta: Four Salemba.

Brigham, E., \& Gapenski. (1996). Intermediate Financial Management. Harbor Drive: Dryden Press.

Cooper, D. R., \& Schindlers. (2006). Business Research Methods. Jakarta: PT. Global media.

Fatemeh Baghiyan. (2013). The Impact of Working Capital Management on Management Performance. Journal of Behavioral Economics, Finance, Entrepreneurship, Accounting and Transport, vol. 1, no. 1 .

Gathogo, G., \&Ragui, D. M. (2014). The Company's capital structure Kenya: What Determines It? Research Journal of Finance and Accounting. 
Gul, S., Khan, M. B., Razzaq, N., \& Saif, N. (2012). How Firm Characteristics Affect the Capital Structure in Banking and Insurance Sector (Case Pakistan). European Journal of Business and Management.

Hamam Roni, Atim Djazuli, and Djumahir. (2018). The Effect of Working Capital, Management On Profitability of State-Owned Enterprise In Processing Industry Sector. Journal Aplication Management, vol. 16, no. 2.

Jensen, M.C and Meckling, W.H. (1976). "Theory of Firm: Managerial Behaviour, Agency Cost and Ownership Structure." Journal of Financial Economics, pp. 305-360.

John. J. Hampton. (1990) . Financial Decision Making Concepts, Problems And Cases, Edisi Keempat, Reprinted in India by special arrangement with Prentice-Hall, Inc., Englewood Cliffs, N. J., USA.

Lukman Purnomosidi, Suhadak, Hermanto Siregar, and M Dzulkirom. (2014). The Influences of Company Size, Capital Structure, Good Corporate Governance, Inflation, Interest Rate, and Exchange Rate of Financial, Performance andValue of The Company. Interdisciplinary Journal of Contemporary Research In Business, vol. 5, no. 10.

Mias Fatimatuzzahra and Retno Kusumastuti.(2016). Determinant of Working Capital Management of Manufacturing Companies. Mimbar, vol. 32, no. 2.

Mustafa Afeef.(2011). Analyzing the Impact of Working Capital Management on The Profitability of SME's in Pakistan. International Journal of Business and Social Science, vol. 2, no. 22.

Myers S.(1984). The Capital Structure Puzzle. Journal of Finance. 39.

Ozkan, A. (2001). Determinants of Capital Structure And Adjustment For Long Term Target: Evidence From UK Company Panel Data. Journal of Business Finance $\mathcal{E}$ Accounting.https://doi.org/10.1111/1468-5957.00370

Rafiq M, Iqbal A, Atiq M.(2008). The Determinant of Capital Structure of the Chemical Industry in Pakistan. The Lahore Jurnal of Economics. 13(1):139- 158.

Taker, Delek et All.(2009)."Determinant of Capital Structure For Turkish Firms : A PanelData Analysis", International Research Journal of Finance and Economics,ISSN 1450-2887 Issue 29,2009.

Weston, J. Fred and Copeland, Thomas E.(1986).Financial Management, Edisi 8, Jilid 2. USA:Hall, Inc. 